\title{
Functional Evaluation of the Spa-Rehabilitation Immediate Effect in The Management of Low Back Pain: Pilot Study in Ouargla, Algeria
}

\author{
Abdelghani MILIANI*1, Hocine CHERID ${ }^{2}$, Mohammed RACHEDI ${ }^{2}$ \\ 1 Department of PMR, Faculty of medicine, University of KM Ouargla, Algeria. \\ 2 Department of PMR, Faculty of medicine, University of Algiers, Algeria. \\ * abdou-dr@live.fr
}

\begin{abstract}
:
The region of Ouargla in the south-east of Algeria has many thermal hot springs that are still largely untapped. The aim of this pilot study is to assess the contribution of balneotherapy in the functional improvement of low back pain patients. Methods: This study concerned non-specific chronic low back pain patients treated at the balneotherapy and rehabilitation center in Ouargla, Algeria. The sample was divided into two groups for comparative purposes: the first one is the intervention group (A) receiving physical therapy combined with balneotherapy, and the second is the control group (B) receiving physical therapy alone. The response was assessed using the Oswestry Disability Index (ODI) in its Arabic version. The questionnaire was given at the beginning and end of treatment. An improvement in Oswestry is considered clinically relevant if it is above $30 \%$. The sensitivity to changes is estimated by the standardized response mean and effect size. Results: Ten patients meeting the eligibility criteria were split equally into the two groups. We observed that $60 \%(3 / 5)$ patients had a clinically relevant improvement in Oswestry in group (A) versus $20 \%(1 / 5)$ patient in group (B). The effect size for group (A) and group (B) is 1.20 and 0.71 , respectively. The standardized response mean is 1.13 for group (A) versus 1.01 for group (B). Conclusion: The results of the present study reiterate that in addition to conventional rehabilitation, balneotherapy can be more effective in the treatment of patients suffering from non-specific chronic low back pain.
\end{abstract}

\section{Keywords: Oswestry Disability Index; Chronic Low Back Pain; Physical Therapy; Balneotherapy; Spa Therapy.}

Crossref doi https://doi.org/10.51345/.v31i1.210.g159 


\section{INTRODUCTION:}

Chronic low back pain (CLBP) constitutes in Algeria, as in many countries, a real public health problem and a frequent reason for consultations in primary care medicine and in specialized structures (Bezzaoucha, 1992, Hoy et al., 2010). CLBP is benign and spontaneously resolving condition in most cases, however its functional impact can sometimes be very important hindering the various activities of daily and professional life (Hartvigsen et al., 2018). For treatment, many tools are disposed, more or less recommended, and non-drug treatments occupy a central place, among which is balneotherapy (Yaraşır et al., 2018). This last is part of the therapeutic arsenal recommended by the major clinical guidelines for the management of CLBP (O'Connell et al., 2016). It appears in the "Recommendations of good clinical practice" published in France by the High Authority for Health (HAS) and at European level by the European League Against Rheumatism (EULAR) (Francon \& Forestier, 2009). These recommendations are based on an analysis of the levels of scientific evidence, including mainly randomized clinical trials (Bai et al., 2019). The results of published trials indicate a persistent improvement in pain, consumption of drugs, function and / or quality of life (Constant et al., 1998, Kulisch, 2016).

Balneotherapy or in other words Spa therapy is based both on the use of natural mineral water and its derivatives for therapeutic purposes, at the place of emergence. The chemical composition and specific activity of natural mineral waters are closely linked, which allows the action of certain categories of natural mineral waters in certain precise indications (Lessard-Jean et al., 2012). The thermal cure is the set of treatment means implemented during the patient's stay in a thermal facility. It is a medical therapy in its own right, it is prescribed by the attending physician and reimbursed by the social security funds (Azouvi et al., 2018). This therapy, which has long been refocused around the "thermal medicine", is today largely reoriented towards "spa-rehabilitation", that is to say thermalism as a "global therapy" and the current trend is oriented towards the development of this type of spa resorts where physical medicine coexists with thermal medicine (Herisson, 2015).

Even in these days in which the world is struggling against COVID-19; if hygienically controlled, spa resorts can be visited for balneotherapy applications, respecting WHO and national recommendations (Masiero et al., 2020, Guvener, 2020). These spa facilities can be a proper setting of respiratory rehabilitation for post-COVID19 patients, with a keen focus on post-infective lung damage and fibrosis. Also, it can be a suitable setting to recover disabilities in patients tested negative for COVID19 discharged from hospital by an integrative and effective management of COVID-19 long-term sequelae (Masiero, Maccarone, \& Agostini, 2020). Furthermore, balneotherapy can be used preventively, because it can lead to the increase of muscle tissue and strengthen the lung capacity surely for the elderly and the people with defective innate immunity (Shin, 2020, Prossegger et al., 2019). And it is also shown that the use of balneotherapy may improve human immune function, both humoral and cell mediated (Masiero, Maccarone, \& Magro, 2020).

In the south-east of Algeria, the region of Ouargla has many thermal springs that are still largely untapped (SAKER, 2013). Among these spa resorts, there is the balneotherapy and rehabilitation center of Ouargla, situated in the heart of the palm groves of the Algerian Desert.

The aim of this study is to assess the contribution of balneotherapy in the function improvement of low back pain patients comparing the immediate effects of a physical therapy combined with spa therapy versus a physical therapy alone. 


\section{MATERIALS AND METHODS:}

\subsection{Sample:}

\subsubsection{Participants:}

The study concerns CLBP patients followed in consultation of physical medicine and rehabilitation (PMR) department in the university hospital of Ouargla, Algeria, and taken care of at the regional center of spa therapy and functional rehabilitation in Ouargla, Algeria.

\subsubsection{Inclusion criteria:}

- Young adult patient aged 18 to 60 ,

- Presenting a common CLBP evolving for more than 3 months and Visual Analog Scale (VAS) of the pain higher than 3/10.,

- Patient living within a radius of less than $50 \mathrm{~km}$ from the spa resort of Ouargla, Algeria and able to perform 2 treatment sessions per week

- Patient agreeing to answer the questionnaires and having signed the participation consent form

\subsubsection{Non-inclusion criteria:}

- Symptomatic CLBP (tumor, infectious, inflammatory, etc.),

- Fibromyalgia.

- Contraindication to spa therapy

- Neurological disorders with sensory and / or motor deficit.

- Major personality disorder,

- Pregnant woman

- Recent trauma or recent surgery (less than 6 months).

\subsubsection{Eligibility criteria:}

A subject is considered eligible if he is a young adult, presenting a common CLBP evolving for more than 03 months.

\subsubsection{Randomization:}

This panel was divided between two equal groups for comparative purposes. The classification in each group is therefore based on the date of patient recruitment: the first half recruited are included in the intervention group (A) receiving balneotherapy combined to physical therapy, and the last half patients recruited are referred to the control group (B) receiving only physical therapy.

\subsection{Study protocol:}

The patients were recruited from June 2018 to March 2019, by two physicians from the department of physical and rehabilitation medicine, University Hospital of Ouargla, experienced in the follow-up of spa therapy and temporary workers at the balneotherapy and rehabilitation center of Ouargla, Algeria, where these patients received their outpatient spa and / or physical therapy.

After having their informed consent, patients meeting the eligibility criteria were divided equally between the two groups according to their date of recruitment: the first arrivals in group (A) of spa 
therapy combined to physical therapy, and the last half in the control group (B) of physical therapy alone. The spa cares as well as the physical treatments are provided by physiotherapists for 04 successive weeks twice a week. Each session includes a set of spa and or physical therapy according to the prescribed protocol, and it takes between 45 to 75 minutes. The smooth running of the session and good tolerance to care are ensured by the physician during treatment follow-up visits. The two groups having the same therapeutic education advice as well as strengthening and flexibility exercises to be performed outside of sessions. The data were collected twice: at the beginning and at the end of processing. The self-assessment questionnaires were completed by the patients without the physician's presence.

During the initial questionnaire, we also collected a number of prognostic factors: age and intensity of the pain, presence of sciatic radiation, etiological diagnosis, history of lumbar surgery. The final assessment is made after 4 weeks of treatment, or 8 sessions. The patient completed the selfquestionnaire at the beginning of the 5th week, and not at the end of the 8th session in order to be as reproducible as possible and so that the answers are not distorted by a specific effect linked to care made during the last session.

\subsection{Treatment protocol:}

\subsubsection{Physical therapy:}

It is the classic rehabilitation of the CLBP patient, performed for all patients in group (A) and group (B) over 08 sessions, spread over 4 consecutive weeks, at the rate of 2 sessions per week. It is prescribed and supervised by a doctor from the spa-rehabilitation center (PMR physician). This physical therapy included the following treatments: a massage, physiotherapy with an exercise program. A session is constructed as follows:

- Relaxing massage of the paravertebral muscles

- Physiotherapy made of infrared and analgesic electrotherapy type TENS

- Warming up by bike or elliptical trainer

- Mobility exercise (flexibility, tilt, lordosis / kyphosis ...)

- Lumbar locking work

- Muscle strengthening of the abdominal, spinal, quadriceps and hamstring muscles.

- Stretching of the muscle groups of the lower limbs.

\subsubsection{Spa therapy:}

Or balneotherapy, it is carried out by thermal water of the balneotherapy and rehabilitation center of Ouargla, which is of the chlorinated and sodium sulphated type. This thermal water reaching 51 degrees with a flow of 200 liters / second comes from a deep borehole located in El-Hadeb, on the heights of the commune of Rouissat, in the heart of the palm groves of Ouargla, in the Algerian Desert. Physicochemical properties and overall mineralization are reported in the table 1 (SAKER, 2013).

This treatment is prescribed and supervised by a physician from the balneotherapy center and includes a combination of the following thermal cares:

- Thermal water bath between $37^{\circ} \mathrm{C}$ and $45^{\circ} \mathrm{C}$ lasting 10 minutes on the spine, shoulder girdle, pelvic girdle and peripheral joints.

- General mobilization pool: supervised swim in a $34^{\circ} \mathrm{C}$ thermal water pool lasting 15 minutes 
- Free swimming pool: simple bathing in a $34^{\circ} \mathrm{C}$ thermal water pool lasting 10 minutes.

Table 1 Physicochemical properties of thermal water from the source of El-Hadeb, Ouargla.

\begin{tabular}{|c|c|}
\hline Date of sampling & $23 / 01 / 2013$ \\
\hline $\mathrm{PH}$ & 7.07 \\
\hline Conductivity at $25^{\circ} \mathrm{C}$ & 2320 \\
\hline Temperature $^{\circ} \mathrm{C}$ & 51 \\
\hline NTU turbidity & 0.57 \\
\hline TDS mg / 1 & 1160 \\
\hline Salinity\% & 1.1 \\
\hline Dry residue at $105^{\circ}$ & 1800 \\
\hline Calcium Ca $+2 \mathrm{mg} / \mathrm{l}$ & 216.34 \\
\hline Magnesium $\mathrm{Mg}+2 \mathrm{mg} / 1$ & 86.4 \\
\hline Sodium $\mathrm{Na}+\mathrm{mg} / \mathrm{l}$ & 200 \\
\hline Potassium K + mg / 1 & 30 \\
\hline Chlorides Cl- mg / 1 & 655.85 \\
\hline Sulfate SO4-2 mg / 1400 & 400 \\
\hline Bicarbonate $\mathrm{HCO} 3-\mathrm{mg} / \mathrm{l}$ & 174.65 \\
\hline Total Hardness $(\mathrm{TH}) \mathrm{mg} / \mathrm{CaCO} 3$ & 900 \\
\hline Full alkaline titer $\mathrm{mg} / \mathrm{CaCO} 3$ & 143.15 \\
\hline Total iron $\mathrm{mg} / \mathrm{l}$ & 0.13 \\
\hline
\end{tabular}

\subsubsection{Combined therapy (Spa-rehabilitation):}

It is the combination of spa therapy with physical therapy. This intervention treatment is reserved only for patients of group (A) doing 08 sessions for 4 consecutive weeks at a rate of 2 sessions per week. Each session begins with physical treatment before moving on to thermal cares.

\subsection{Evaluation criteria:}

Several parameters must be taken into account when evaluating CLBP, in particular pain, spinal mobility, the strength of muscular elements but above all functional incapacity, which is why the main outcome measure chosen was the ODI, a functional scale specific for low back pain (Fairbank et al., 1980). This scale is one of the most used indices (Vogler et al., 2008, Boscainos et al., 2003, Davidson \& Keating, 2002), and moreover it is the only functional index that has translated and validated in an Arabic population. Currently, it is the only functional index available in Arabic (Guermazi et al., 2005, Algarni et al., 2014). We chose to use the modified Arabic version of the Oswestry index (version 8 items) because of its simplicity. This version is translated and written in an easy literary Arabic language close to the North African dialect (Guermazi et al., 2005). This version contains eight items with six response levels ranging from 0 to 5 . A total score is established as a percentage of disability (score obtained divided by 40 then multiplied by 100) and ranges from $0 \%$ (no disability) to $100 \%$ (total incapacity). (Annex A). 
The evaluation of patients by the Oswestry self-questionnaire was carried out in two measures: in M1 before the beginning of treatment and in M2 after the end of the protocol. An improvement in Oswestry was considered clinically relevant if it was greater than $30 \%$ (Ostelo et al., 2008).

\subsection{Statistical methods:}

The statistical analyses were performed using the SPSS 25.0 program. The descriptive analysis focuses on the main variables collected. We use the numbers (n) and percentages (\%) for the qualitative variables, and the means and standard deviation (SD) for the continuous variables. For the comparative analysis of the evolution of the ODI within each group, we used the non-parametric statistical test of Wilcoxon for paired series due to the small size of our sample. For the comparative analysis of the clinically relevant improvement in the ODI between the two groups, we used McNemar's statistical test. A p-value less than 0.05 is considered significant. To estimate the sensitivity to change of the ODI in each group, we calculated two indices to assess the treatment effect: the standardized response mean (SRM) and the size of the effect (the effect size). The Standardized Response Mean (SRM), is equal to the difference between the mean before treatment and that after treatment, divided by the standard deviation of the differences between the results. The Effect Size (ES) corresponds to the difference between the mean before treatment and that after treatment, divided by the standard deviation before treatment. The treatment effect is considered weak if it is less than 0.50 , as moderate between 0.51 and 0.80 and as important greater than 0.80 (Norman \& Streiner, 2008).

\section{RESULTS:}

\subsection{Patient's baseline data:}

Ten patients meeting the eligibility criteria were split equally into the two groups. The characteristics of the radio-clinical profile of participants at inclusion are described in table 2.

Table 2 Characteristics of the patients included. (Data are shown as mean $\pm \mathrm{SD}$ ).

\begin{tabular}{llll}
\hline & All patients & Group (A) & Group (B) \\
\hline Number of subjects & 10 & 5 & 5 \\
Age (year) & $30.80 \pm 6.35$ & $29.20 \pm 2.49$ & $32.40 \pm 8.85$ \\
Sex-ratio & $10 / 0$ & $5 / 0$ & $5 / 0$ \\
Pain (VAS 100) & $63.29 \pm 14.86$ & $61.50 \pm 19.09$ & $64.00 \pm 15.16$ \\
Pain duration (months) & $38.67 \pm 40.40$ & $28.50 \pm 37.51$ & $46.80 \pm 44.98$ \\
Low back pain & $04(40 \%)$ & $02(40 \%)$ & $02(40 \%)$ \\
Lumbo-sciatica & $06(60 \%)$ & $03(60 \%)$ & $03(60 \%)$ \\
Disc pathology & $07(70 \%)$ & $03(60 \%)$ & $04(80 \%)$ \\
Static disorders & $03(30 \%)$ & $02(40 \%)$ & $01(20 \%)$ \\
\hline
\end{tabular}




\subsection{Evolution of the ODI:}

Table 3 The ODI score before and after treatment into the two groups

\begin{tabular}{llllllll}
\hline Group (A) & M1 & M2 & $\begin{array}{l}\text { Improvement } \\
\text { rate (\%) }\end{array}$ & Group (B) & M1 & M2 & $\begin{array}{l}\text { Improvement } \\
\text { rate (\%) }\end{array}$ \\
\hline Patient 1 & 47,5 & 32,5 & $+31,58$ & Patient 6 & 25 & 30 & -20 \\
Patient 2 & 65 & 35 & $+46,15$ & Patient 7 & 32,5 & 22,5 & $+30,77$ \\
Patient 3 & 37,5 & 22,5 & +40 & Patient 8 & 35 & 25 & $+28,57$ \\
Patient 4 & 57,5 & 57,5 & +00 & Patient 9 & 47,5 & 40 & $+15,79$ \\
Patient 5 & 45 & 40 & $+11,11$ & Patient 10 & 47,5 & 35 & $+26,32$ \\
\hline
\end{tabular}

Table 4 Sensitivity to change of the ODI in each group

\begin{tabular}{llllllc}
\hline Group & M1 & M2 & $\Delta$ (M1-M2) & ES & SRM & p-Value \\
\hline Group (A) & $50.50 \pm 10.81$ & $37.50 \pm 12.87$ & $13 \pm 11.51$ & 1.20 & 1.13 & 0.066 \\
Group (B) & $37.50 \pm 9.84$ & $30.50 \pm 7.16$ & $07 \pm 6.93$ & 0.71 & 1.01 & 0.078 \\
\hline
\end{tabular}

We observed that in group (A) performing spa therapy combined with physical therapy, there was a clinically relevant improvement in Oswestry in $3 / 5(60 \%)$ patients, compared to $1 / 5$ (20\%) patients only in group (B) performing physical therapy alone. (Table 3).

In group (A), there is a good improvement in the score of ODI, the gain obtained on average is $25.76 \pm$ $19.56 \%$, with a decrease of 13 points for Oswestry. In group (B), there is a less significant improvement in the Oswestry score, the gain obtained on average is $16.28 \pm 21.08 \%$ with a decrease of 07 points for ODI.

The effect size in the two groups (A) and (B) is 1.20 and 0.71 respectively. The standardized response mean is 1.13 for group (A) versus 1.01 for group (B). Wilcoxon's statistical test was not significant but $\mathrm{p}$-value is not far from 0.05 . The difference between the two groups in terms of clinically relevant improvement was not significant according to McNemar's test with p-value at 0.500. (Table 4).

\subsection{Side effects:}

No serious adverse events occurred during the study. The treatment took place without interruption and without modification for all the participants.

\section{DISCUSSION:}

\subsection{On the results:}

Analysis of the results of our study made it possible to observe significant variations in Oswestry in the intervention group and that the patients with a clinically relevant improvement are a majority in this group ( $3 / 5$ versus $1 / 5$ in the control group). The sensitivity to the change in this endpoint reflects this finding. The calculated value of the standardized response means greater than 0.8 suggests that spa therapy combined with physical therapy could have a large-scale therapeutic effect on function. 
If the study could not highlight a significant difference between the two groups because of its power, there is however a notable improvement in the score of Oswestry in the two groups but more significant in the combined therapy group. These results suggest the superior efficacy of the combination of spa therapy to physical therapy versus physical therapy alone in improving function in CLBP patients. This superiority of efficiency can be explained by numerous hypotheses. First, the discharge effect caused by immersion in thermal water allows better body mobilization. Secondly, the heat of the thermal water has an effect on muscle relaxation. Finally, the reassuring effect of balneotherapy could combat the kinesiophobia from which a good part of CLBP patients suffer.

The absence of adverse events during our study is in favor of the safety of thermal and or physical treatment.

\subsection{Strengths and weaknesses of the study:}

For the first time in Algeria, this study made it possible to test the contribution of spa therapy in restoring function in CLBP, in comparison with a control group. The originality of our study also resides in the criterion of judgments, in particular the functional evaluation by a validated scale in the mother tongue of the patients, which allows us to have a more objective evaluation.

The concept of traditional spa therapy requires at least 2 to 3 weeks of treatment in a spa resort. This inpatient mode may seem very restrictive for workers, the reason why we opted for physical and / or spa therapy to be provided on an outpatient basis. Although it has demonstrated efficacy (Yücesoy et al., 2019), this mode of treatment can have a less significant effect by adding to the classic cure (Özkuk et al., 2018).

However, the interpretation of our results must remain cautious given the limitations of our study: a small number and of course the absence of good randomization constitute important methodological biases in the analysis of our results. Then there is a tracking bias. When asking patients to perform home exercises, it cannot be accurately assessed whether the exercise frequency guidelines and recommendations have been followed.

It should also be noted that the evaluation was carried out without the knowledge of the patient and the evaluating physician. These evaluating physicians are also the patient's therapists, which may have led some patients to overestimate the effect of spa therapy to please their doctor. Finally, the evaluation only estimated that the immediate effect observed at the end of the treatment, it would have been interesting to be able to follow the evolution of the results obtained in the medium and long term to see if the benefits of the treatment are persistent.

\subsection{Comparison to previous studies:}

We find in the literature some similar studies comparing the immediate effect on the function of the combination of spa therapy with usual treatments versus a control group and which showed the superiority of this combination for ODI at the end of the priest. The sensitivity to change in the Oswestry index is assessed by analyzing the Effect Size (ES) calculated in each group. The characteristics of these studies are summarized in Table 5.

Unlike other studies on the subject, in the study of Onat et al., 2014, the thermal group showed better results concerning pain, mobility and quality of life, however this combined therapy did not bring any additional benefit to Oswestry compared to the control group. 
In our study, there is a clinically relevant improvement in $60 \%$ of patients in the intervention group. This result is clearly higher than that observed in an uncontrolled pilot study by Forestier et al. 2011 on the same subject where only $18.75 \%$ (3 / 16patients) had a clinically relevant improvement in Oswestry measured at the end of the treatment (Forestier \& Francon, 2011). The same author conducted another study in 2017 where the rate of clinically relevant improvement after the cure reached $76.2 \%$ (Forestier, 2017).

Table 5 Characteristics of similar studies analyzed and compared

\begin{tabular}{|c|c|c|c|c|c|c|}
\hline Study & $\begin{array}{l}\text { Intervention } \\
\text { (combined with spa } \\
\text { therapy) }\end{array}$ & $\begin{array}{l}\text { Control } \\
\text { (No spa therapy) }\end{array}$ & $\begin{array}{l}\text { First evaluation } \\
\text { after }\end{array}$ & $\begin{array}{l}\text { Sample } \\
\text { size }\end{array}$ & $\begin{array}{l}\text { ES in } \\
\text { Spa } \\
\text { group }\end{array}$ & $\begin{array}{l}\text { ES in } \\
\text { control } \\
\text { group }\end{array}$ \\
\hline $\begin{array}{l}\text { Demirel et al., } \\
2008\end{array}$ & $\begin{array}{l}\text { Spa therapy }+ \\
\text { Exercise program }\end{array}$ & Exercise program & $\begin{array}{l}\text { 03 weeks } \\
\text { (15 sessions) }\end{array}$ & 44 & 0.57 & 0.45 \\
\hline $\begin{array}{l}\text { Kulisch et al., } \\
2009\end{array}$ & $\begin{array}{l}\text { Spa therapy + } \\
\text { Electrotherapy }\end{array}$ & $\begin{array}{l}\text { Hydrotherapy + } \\
\text { Electrotherapy }\end{array}$ & $\begin{array}{l}03 \text { weeks } \\
\text { (15 sessions) }\end{array}$ & 71 & 0.60 & 0.19 \\
\hline $\begin{array}{l}\text { Kesiktas et al., } \\
2012\end{array}$ & $\begin{array}{l}\text { Spa therapy }+ \\
\text { Exercises }+ \\
\text { Patient education }\end{array}$ & $\begin{array}{l}\text { Physical therapy + } \\
\text { Exercises }+ \\
\text { Patient education }\end{array}$ & $\begin{array}{l}02 \text { weeks } \\
\text { (10 sessions) }\end{array}$ & 60 & 0.70 & 0.40 \\
\hline $\begin{array}{l}\text { Dogan et al., } \\
2011\end{array}$ & $\begin{array}{l}\text { Spa therapy + } \\
\text { Physical therapy }\end{array}$ & Physical therapy & $\begin{array}{l}03 \text { weeks } \\
\text { (15 sessions) }\end{array}$ & 60 & 2.14 & 1.36 \\
\hline $\begin{array}{l}\text { Onat et al., } \\
2014\end{array}$ & $\begin{array}{l}\text { Spa therapy }+ \\
\text { Physical therapy }+ \\
\text { Home exercise }\end{array}$ & $\begin{array}{l}\text { Physical therapy }+ \\
\text { Home exercise advice }\end{array}$ & $\begin{array}{l}03 \text { weeks } \\
\text { (15 sessions) }\end{array}$ & 81 & 2.52 & 2.85 \\
\hline $\begin{array}{l}\text { Huber et al., } \\
2019\end{array}$ & $\begin{array}{l}\text { advice } \\
\text { Spa therapy }+ \\
\text { Green exercise }\end{array}$ & $\begin{array}{l}\text { Green exercise } \\
\text { Physical therapy }\end{array}$ & $\begin{array}{l}01 \text { week } \\
\text { (06 sessions) }\end{array}$ & 80 & 0.79 & 0.74 \\
\hline Our study & $\begin{array}{l}\text { Spa therapy + } \\
\text { Physical therapy }\end{array}$ & & $\begin{array}{l}04 \text { weeks } \\
\text { (08 sessions) }\end{array}$ & 10 & 1.20 & 0.70 \\
\hline
\end{tabular}

\section{CONCLUSION:}

Although physical therapy is effective for chronic low back pain, the combination of spa therapy with physical therapy (spa-rehabilitation) as multimodal therapy may be more effective in providing relevant short-term improvement in functional capacity compared to physical therapy alone.

Therefore, spa therapy using Ouargla thermal water could be considered for inclusion in the rehabilitation program for patients suffering from CLBP.

These preliminary results should be complemented by other large-scale studies which make it possible to assess the long-term effects and the durability of this combined therapy.

\section{DISCLOSURE OF INTEREST}

The authors declare that they have no conflicts of interest concerning this article. 


\section{ACKNOWLEDGMENT}

We would like to thank the two physiotherapists: Khaled EMBAREK and Malek KERCHOUCHE and all of the staff at the Balneotherapy and Rehabilitation Center of Ouargla, Algeria.

\section{REFERENCING}

Algarni, A. S., Ghorbel, S., Jones, J. G., \& Guermazi, M. (2014). Validation of an Arabic version of the Oswestry index in Saudi Arabia. Annals of Physical and Rehabilitation Medicine, 57(910), 653-663.

Azouvi, P., Beaudreuil, J., Benaïm, C., Bensoussan, L., Bonan, I., Bouillet, B., Boutevillain, L., Brochard, S., Coudeyre, E., \& Courtois-Jacquin, S. (2018). Médecine physique et de réadaptation: Réussir les ECNi. Elsevier Health Sciences.

Bai, R., Li, C., Xiao, Y., Sharma, M., Zhang, F., \& Zhao, Y. (2019). Effectiveness of spa therapy for patients with chronic low back pain: An updated systematic review and meta-analysis. Medicine, 98(37).

Bezzaoucha, A. (1992). Descriptive epidemiology of low-back pain in Algiers. Revue Du Rhumatisme et Des Maladies Osteo-Articulaires, 59(2), 121-124.

Boscainos, P. J., Sapkas, G., Stilianessi, E., Prouskas, K., \& Papadakis, S. A. (2003). Greek versions of the Oswestry and Roland-Morris disability questionnaires. Clinical Orthopaedics and Related Research®, 411, 40-53.

Constant, F., Guillemin, F., Collin, J. F., \& Boulangé, M. (1998). Use of spa therapy to improve the quality of life of chronic low back pain patients. Medical Care, 36(9), 1309-1314.

Davidson, M., \& Keating, J. L. (2002). A comparison of five low back disability questionnaires: reliability and responsiveness. Physical Therapy, 82(1), 8-24.

Demirel, R., Ucok, K., Kavuncu, V., Gecici, O., Evcik, D., Dundar, U., Solak, O., \& Mollaoglu, H. (2008). Effects of balneotherapy with exercise in patients with low back pain. Journal of Back and Musculoskeletal Rehabilitation, 21(4), 263-272.

Dogan, M., Sahin, O., Elden, H., Hayta, E., \& Kaptanoglu, E. (2011). Additional therapeutic effect of balneotherapy in low back pain. South Med J, 104(8), 574-578.

Fairbank, J. C., Couper, J., Davies, J. B., \& O’brien, J. P. (1980). The Oswestry low back pain disability questionnaire. Physiotherapy, 66(8), 271-273.

Forestier, R. (2017). 61. Evolution clinique de l'arthrose après une cure thermal, étude ouverte sur 111 patient. Forestier R, Malié D Briançon G. Press Therm Clim 2017 ;154:49-78. Press Therm Clin, 154.

FORESTIER, R., \& FRANCON, A. (2011). Etude pilote sur la lombalgie chronique en cure thermale: évaluation de trois critères de jugement. La Presse Thermale et Climatique, 148, 115-125.

Francon, A., \& Forestier, R. (2009). Spa therapy in rheumatology. Indications based on the clinical guidelines of the French National Authority for health and the European League Against Rheumatism, and the results of 19 randomized clinical trials. Bulletin de l'Académie Nationale de Médecine, 193(6), 1345-1348.

Guermazi, M., Mezghani, M., Ghroubi, S., Elleuch, M., Med, A. O., Poiraudeau, S., Mrabet, F., Dammak, J., Fermanian, J., \& Baklouti, S. (2005). The Oswestry index for low back pain translated into Arabic and validated in a Arab population. Annales de Readaptation et de Medecine Physique: Revue Scientifique de La Societe Francaise de Reeducation Fonctionnelle de Readaptation et de Medecine Physique, 48(1), 1-10. 
Guvener, O. (2020). Balneotherapy in the era of COVID-19: should it be recommended or not? International Journal of Biometeorology, 1.

Hartvigsen, J., Hancock, M. J., Kongsted, A., Louw, Q., Ferreira, M. L., Genevay, S., Hoy, D., Karppinen, J., Pransky, G., \& Sieper, J. (2018). What low back pain is and why we need to pay attention. The Lancet, 391(10137), 2356-2367.

Herisson, C. (2015). LA FORMATION SPÉCIALISÉE EN MÉDECINE THERMALE CAPACITÉ, DU, DIU BESOINS ET ENJEUX. La Presse Thermale et Climatique, 152, 87.

Hoy, D., Brooks, P., Blyth, F., \& Buchbinder, R. (2010). The epidemiology of low back pain. Best Practice \& Research Clinical Rheumatology, 24(6), 769-781.

Huber, D., Grafetstätter, C., Proßegger, J., Pichler, C., Wöll, E., Fischer, M., Dürl, M., Geiersperger, K., Höcketstaller, M., \& Frischhut, S. (2019). Green exercise and mg-ca-SO 4 thermal balneotherapy for the treatment of non-specific chronic low back pain: a randomized controlled clinical trial. BMC Musculoskeletal Disorders, 20(1), 221.

Kesiktas, N., Karakas, S., Gun, K., Gun, N., Murat, S., \& Uludag, M. (2012). Balneotherapy for chronic low back pain: a randomized, controlled study. Rheumatology International, 32(10), 3193-3199.

Kulisch, Á. (2016). Efficacy of balneotherapy on pain, function and quality of life in patients with chronic low back pain, and hand or knee osteoarthritis. szte.

Kulisch, Á., Bender, T., Németh, A., \& Szekeres, L. (2009). Effect of thermal water and adjunctive electrotherapy on chronic low back pain: a double-blind, randomized, follow-up study. Journal of Rehabilitation Medicine, 41(1), 73-79.

Lessard-Jean, L., Juneau, A., Laplante-Dieumegarde, Y., \& Laplante-Rayworth, C. (2012). L'hydrothérapie: une approche globale de traitement en physiothérapie.

Masiero, S., Maccarone, M. C., \& Agostini, F. (2020). Health resort medicine can be a suitable setting to recover disabilities in patients tested negative for COVID-19 discharged from hospital? A challenge for the future. International Journal of Biometeorology, 1.

Masiero, S., Maccarone, M. C., \& Magro, G. (2020). Balneotherapy and human immune function in the era of COVID-19. International Journal of Biometeorology, 1-2.

Norman, G. R., \& Streiner, D. L. (2008). Biostatistics: the bare essentials. PMPH USA.

O'Connell, N. E., Cook, C. E., Wand, B. M., \& Ward, S. P. (2016). Clinical guidelines for low back pain: A critical review of consensus and inconsistencies across three major guidelines. Best Practice \& Research Clinical Rheumatology, 30(6), 968-980.

Onat, Ş. Ş., Taşoğlu, Ö., Güneri, F. D., Özişler, Z., Safer, V. B., \& Özgirgin, N. (2014). The effectiveness of balneotherapy in chronic low back pain. Clinical Rheumatology, 33(10), $1509-1515$.

Ostelo, R. W. J. G., Deyo, R. A., Stratford, P., Waddell, G., Croft, P., Von Korff, M., Bouter, L. M., \& Henrica, C. (2008). Interpreting change scores for pain and functional status in low back pain: towards international consensus regarding minimal important change. Spine, 33(1), 90-94.

Özkuk, K., Uysal, B., Ateş, Z., Ökmen, B. M., Sezer, R., \& Dilek, G. (2018). The effects of inpatient versus outpatient spa therapy on pain, anxiety, and quality of life in elderly patients with generalized osteoarthritis: a pilot study. International Journal of Biometeorology, 62(10), 1823-1832.

Prossegger, J., Huber, D., Grafetstätter, C., Pichler, C., Weisböck-Erdheim, R., Iglseder, B., Wewerka, G., \& Hartl, A. (2019). Effects of moderate mountain hiking and balneotherapy on 
community-dwelling older people: A randomized controlled trial. Experimental Gerontology, 122, 74-84.

SAKER, M. L. (2013). Les ressources en eaux et leurs conséquences sur l'environnement oasien: cas région de Ouargla.

Shin, H.-S. (2020). Empirical Treatment and Prevention of COVID-19. Infection \& Chemotherapy, 52.

Vogler, D., Paillex, R., Norberg, M., De Goumoëns, P., \& Cabri, J. (2008). Validation transculturelle de l'Oswestry disability index en français. Annales de Réadaptation et de Médecine Physique, 51(5), 379-385.

Yaraşır, E., Pirinçci, E., \& Deveci, S. (2018). Bel Ağrısında Tamamlayıcı ve Alternatif Tedavi. Arşiv Kaynak Tarama Dergisi, 27, 93-108. https://doi.org/10.17827/aktd.342583

Yücesoy, H., Geçmen, İ., Adıgüzel, T., Karagülle, M., \& Karagülle, M. Z. (2019). Efficacy of balneological outpatient treatment (hydrotherapy and peloidotherapy) for the management of chronic low back pain: a retrospective study. International Journal of Biometeorology, 63(3), 351-357. 